\title{
Trial by Fire
}

\section{Improving Our Ability to Reduce Wildfire Impacts to Sage-Grouse and Sagebrush Ecosystems Through Accelerated Partner Collaboration}

\author{
By Tim Murphy, David E. Naugle, Randall Eardley, Jeremy D. Maestas, \\ Tim Griffiths, Mike Pellant, and San J. Stiver
}

\begin{abstract}
On the Ground
- Conservation partners across 11 western states are rallying in unprecedented fashion to reduce threats to sage-grouse and the sagebrush ecosystem they occupy.

- Improvements made in the Bureau of Land Management's (BLM) wildfire policy are a tremendous step forward but the 2012 wildfire season is a harsh reminder that more action is needed to improve our effectiveness in reducing impacts to sage-grouse.

- Challenges and opportunities presented here are intended to heighten awareness of the wildfire issue and to further accelerate a mutually agreed upon, spatially explicit path forward, so that all partners can quickly engage in its implementation.
\end{abstract}

Keywords: Great Basin, fuels management, landscape approach, partnerships, sagegrouse, cheatgrass, wildfire

Rangelands 35(3):2-10

doi: 10.2111/RANGELANDS-D-13-00009.1

(C) 2013 The Society for Range Management

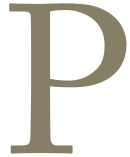

artners across 11 western states are rallying in unprecedented fashion to reduce threats to greater sage-grouse (Centrocercus urophasianus) and the sagebrush ecosystem they occupy (Fig. 1). Actions are spurred by the March 2010 finding issued by U.S. Fish and Wildlife Service (FWS) that sage-grouse warrant protection under the federal Endangered Species Act (ESA), but are precluded until 2015 by higher priority actions. ${ }^{1}$ The FWS identified two overarching factors that resulted in the "warranted but precluded" determination - the inadequacy of existing regulatory mechanisms to protect habitats, and habitat loss and fragmentation.

Classifying sage-grouse as a "candidate" species provides a window of opportunity for partners to proactively negate the need for listing through demonstrated and effective habitat conservation. Investments in sagebrush conservation have increased dramatically as partners put policies and programs in place to reduce fragmenting threats, and implement beneficial conservation practices in priority landscapes. Actions include expedited revisions of land use management plans by the Bureau of Land Management (BLM) and the Forest Service to incorporate conservation measures and regulatory safeguards for sage-grouse, and implementation of a myriad of state- and local-based solutions such as the Wyoming Governor's Sage-Grouse Executive Order that reduces the energy footprint in high-abundance sage-grouse "core areas." A relative newcomer to the scene, the Natural Resources Conservation Service's (NRCS) Sage-Grouse Initiative has helped $>700$ ranchers implement proactive, incentive-based conservation practices designed to improve rangeland health and sage-grouse populations through sustainable ranching.

Despite progress, more is possible, and decision-makers seek solutions to unresolved threats facing sage-grouse. Wildfire and the associated invasion of exotic annual grasses in the Great Basin are two such threats that continue to challenge land managers and impede conservation success. ${ }^{2-5}$ Concerns over these threats are exacerbated by the degraded state of sagebrush ecosystems and difficulty in rehabilitation, particularly at lower elevations. ${ }^{6,7}$

Wildfire and fuels managers have an important role to play in addressing these threats, but by definition, that role is limited to the realm of reducing the likelihood of a fire and its impacts, and is only one 
facet of a multi-pronged and long-term approach needed in the Great Basin. In particular, wildfire and fuels management efforts can help hold the line short term, while other land managers implement long-term solutions to improve ecosystem health and resiliency. Further collaboration between the fire and fuels community and wildlife, range, and other resource professionals is needed to apply a strategic and spatially explicit plan that protects priority habitat for species of concern in the near term and buys time for conservationists to implement a much broader suite of measures to repair a degraded ecosystem over the

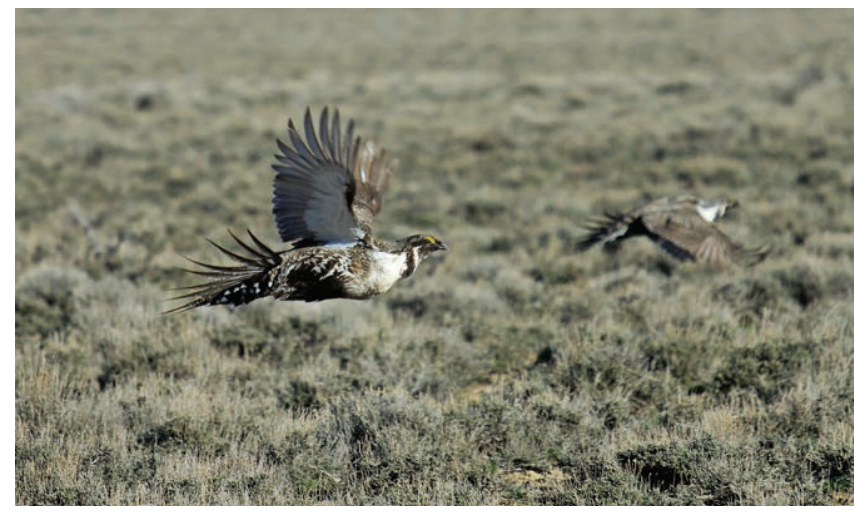

Figure 1. Greater sage-grouse males take flight over the sagebrush ecosystem where partners are working to reduce wildfire impacts. Photo courtesy of Tatiana Gettelman. long term.

The idea for our paper follows on the heels of the newly released Near-Term Greater Sage-Grouse Conservation Action Plan. ${ }^{6}$ This document, prepared by sage-grouse experts at the request of the Western Governors' Sage-Grouse Task Force, identifies specific measures that can be taken in the short term to reduce threats, benefit birds, and potentially negate the need for federal protection. ${ }^{6}$ In the plan, sage-grouse experts suggest that the conservation community more fully engage with the National Interagency Fire Center (NIFC), including fuels management and fire operations expertise to help flesh out a strategic response to reduce wildfire and annual grass threats.

Our purpose here is to: 1) increase awareness about actions already underway on the fire and fuels management front to reduce wildfire risks to sage-grouse specifically, 2) identify some challenges and opportunities for further reducing wildfire impacts, and 3) advance the dialogue among partners about how to improve our collective effectiveness at achieving desired outcomes.

\section{The Overarching Threat}

While much debate can be had about the relative frequency of historic fire in the sagebrush ecosystem, it is important to acknowledge that fire has always played a role as a disturbance factor. ${ }^{4,5}$ Generally speaking, lower elevations experienced much less frequent fires than upper elevation sagebrush communities. ${ }^{4} \mathrm{~A}$ century of fire suppression has greatly altered those historic fire regimes across all sagebrush systems. Today, we are left with a management paradox of both too much fire and too little fire. Too little fire at upper elevations, characterized by mountain big sagebrush (Artemisia tridentata spp. vaseyana), has allowed conifer expansion into sagebrush communities on a massive scale. Too much fire at lower elevations, characterized by Wyoming big sagebrush (Artemisia tridentata spp. wyomingensis), is resulting in wholesale habitat conversion to exotic annual grasslands. ${ }^{8}$

Wildfire in both upper and lower elevation sagebrush communities may be of concern now for a variety of ecological and human reasons. Sagebrush is intolerant of fire and recolonization after fire can take several decades or more in lower elevations, which presents a serious concern for managers seeking to maintain stable populations of wildlife species dependent upon sagebrush, such as sage-grouse. Due to the lack of fire in higher elevations, fuels have increased over time in many places which set the stage for dangerous and often destructive fire events that can threaten life, property, and watershed values.

From an ecological perspective, wildfire in lower elevations is particularly worrisome given the presence of exotic species. For the latter half of the 20th century, land managers across the Great Basin have witnessed vast tracts of intact sagebrush rangelands converted to invasive weeds and exotic annual grasses, most notably cheatgrass (Bromus tectorum). ${ }^{4,8}$ This vicious cycle plays out almost yearly from Oregon to Utah and Idaho to Nevada: cheatgrass, which is highly flammable and provides a continuous fuel bed, accelerates the pace and scope of fires in the sagebrush ecosystem. ${ }^{4,5}$ Postfire rehabilitation efforts often don't result in long-term success in re-establishing sagebrush and native grasses and forbs where there is competition with cheatgrass in fire-disturbed areas. ${ }^{6,7}$ In the worst cases, burned sites cross a threshold to a new state dominated by annual grasslands. ${ }^{8}$ Repeated fires in subsequent years result in expansion of annual grasslands into adjacent sagebrush ecosystems. Over time, this self-perpetuating cheatgrass-wildfire 
cycle results in large-scale loss of sagebrush landscapes that previously provided many ecosystem functions, such as habitat for sage-grouse and other sagebrush-dependent species.

\section{An Update on an Evolving Wildfire and Fuels Management Approach 1999, Large-Scale Fires Spur Change}

Dry lightning storms in 1999 ignited hundreds of fires that burned about 1.7 million acres in little more than a week across the Great Basin - a watershed moment in the Western fire management world. The scale of those fires in that short a period brought together resource specialists to review the consequences. What they found was a significant blow to an already downward trend in ecological resiliency in the face of increasing dominance by annual grasses and other invasive weeds. Clearly, proactive measures, beyond rehabilitation after a fire, were needed to thwart a continuing and disastrous downward ecological spiral. Those findings, and that group, led to the formation of the Great Basin Restoration Initiative (GBRI).

Findings of the GBRI in 1999, combined with continual calls to federally protect sage-grouse, served as a catalyst for BLM fire program leaders to consider how fire management can contribute to sage-grouse conservation. The results were a comprehensive set of best management practices in fire and fuels management and in agency guidance regarding actions inside sage-grouse habitat.

Initially, work among resource advisors and fire managers at some local district levels produced maps identifying important sagebrush areas and known and expected sage-grouse habitat. These early maps were shared with fire dispatchers and crew leaders largely as an awareness tool. Over time, that awareness spread, maps were refined and approaches to planning, fire operations in critical habitat areas, and postfire efforts evolved. Fuels management efforts also evolved to focus projects on protecting sage-grouse habitat.

\section{1, New National Policy Institutionalizes Sweeping Measures}

What started as localized guidance a decade ago has now become policy in fire and fuels management as part of the BLM's overall National Strategy for the conservation of sage-grouse habitat. In a June 2011 Instruction Memorandum (IM) No. 2011-138, ${ }^{9}$ the BLM laid out policy guidance to augment protection of sage-grouse on BLM lands noting that "fire and fuels management functions will contribute to conservation of these species (Gunnison sage-grouse and greater sage-grouse) through planning processes, sage-grouse maps, fire management decision and best management practices."

On a broad scale, the IM directs the Wildland Fire Decision Support System (WFDSS) - a webbased tool to assist fire managers and analysts in making strategic and tactical decisions on fires that escape initial attack - to include consideration of sage-grouse habitat locations. At a state level, those managing sage-grouse habitat "will develop specific resources that reflect local conditions." Those resources may include fuels project design criteria and detailed best management practices focused specifically on local conditions.

Policy also directs fuels treatment prioritization to "address sage-grouse habitat conservation in project design, treatment location and documentation" through the use of local toolboxes, national resources, and best management practices. Working with state wildlife agencies, maps have been updated showing Preliminary General Habitat and Preliminary Priority Habitat. These are localized and have been shared with dispatch offices, fire crew bosses, and other field-going fire responders. Sage-grouse "toolboxes" are now available for each management level—from fire bosses to line managers - that include the maps, resource advisor contact information, and lists of best management practices.

Protocols have now been developed to ensure that Resource Management and Fire Management plans are current and include guidance for management of sage-grouse and sage-grouse habitat. Guidance is provided to ensure fire suppression priorities include critical resources, including sage-grouse habitat, and these priorities are used during periods of fire activity to prioritize incidents and assign resources. The BLM now uses Predictive Services forecasts to pre-position fire crews, equipment, and aircraft in areas expected to experience fire ignitions (Fig. 2). On critical fire weather days, this information is used to preposition additional fire suppression resources to optimize a quick and efficient response in sage-grouse habitat.

When a fire is reported, dispatchers use GIS maps in WildCAD, a computer-aided dispatching tool, to determine if the fire is within or near sage-grouse habitat, and dispatch appropriate resources, as well as relay this information to those responding. A Resource Advisor with on-the-ground knowl- 
edge of resources at risk engages early in the process when habitat is threatened and that advisor works with the incident fire leadership to aid in minimizing habitat loss or further fragmentation. On-the-ground incident managers, trained in the importance of habitat protection and fire suppression tactics, direct operations to minimize impacts to habitat, including suppressing large interior islands of unburned sagebrush that previously would have been allowed to burn out. If additional response resources are brought in, they are briefed on the importance of conserving habitat before being deployed.

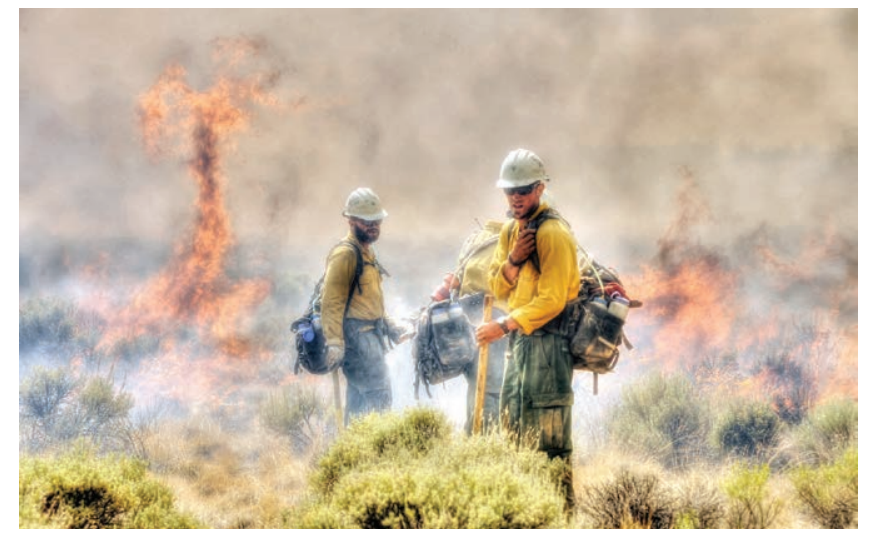

Figure 2. Firefighting crews are increasingly being prepositioned and equipped with information to protect priority sagebrush landscapes. Photo courtesy of Kevin Abel.

\section{Wildfires: A Harsh Reminder of the Need for More Action}

Policy improvements are a tremendous step forward but the 2012 wildfire season is a harsh reminder that more action is needed to improve our effectiveness in reducing impacts to sage-grouse in priority landscapes. Finding agreed-upon ways to reduce wildfire impacts is paramount to achieving desired outcomes for sage-grouse because loss of sagebrush habitats will continue to challenge land managers as fire seasons become longer, hotter, and drier. ${ }^{10}$

Nationally, more than nine million acres burned in wildfires, surpassing the nine-million-acre mark for only the third time in the history of fire record-keeping. All three of those years occurred in the past decade. For sage-grouse, the wildfire issue is predominantly a fragmenting threat to the western half of its range (Fig. 3). Approximately 2.7 million acres burned in 2012 were in sage-grouse habitat, an area equaling nearly two percent of the species' occupied range (Table 1). Moreover, roughly 1.8 million acres burned were inside of priority sage-grouse habitats.

\section{Some Challenges and Opportunities in Need of Partner Engagement}

While significant changes have been implemented to prioritize sage-grouse in fire and fuels management in the last decade, numerous challenges lay ahead and innovative solutions developed collaboratively among all partners are needed. We present a short and nonexhaustive list of some areas in need of accelerated partner engagement to reduce detrimental impacts associated with wildfires.

\section{Need for a Strategic Landscape Approach}

Limited resources and the scale of habitat fragmentation necessitate a strategic approach that targets available resources to the places that maximize our conservation return-on-investment. Land managers require spatially explicit tools and strategies that consider the needs of sage-grouse in the context of the whole ecosystem and allow for better prioritization and targeting of efforts towards places where they are most needed and likely to be successful — even if they occur outside priority sage-grouse habitats.

For example, identifying sagebrush sites where native bunchgrasses are present but at high risk of conversion to annual grasses could help focus prefire land management actions to improve rangeland health. Maintaining and enhancing deep-rooted perennial bunchgrasses is thought to play an important role in increasing ecosystem resiliency and the capacity to respond favorably when fire occurs. ${ }^{6-8}$ Additionally, preventing intact sagebrush sites from crossing ecological thresholds to annual grasslands should be of the utmost importance given the challenges and costs associated with rehabilitation. Conversely, sites already dominated by annual grasses that are low value sage-grouse habitat today, might be priorities for prepositioning of fire resources and proactive fuels management practices (e.g., firebreaks, greenstripping, targeted grazing) to avoid future spread into high-value habitat in the surrounding landscape.

A strategic landscape approach is needed to integrate our understanding of priority sage-grouse habitats with risk factors that undermine rangeland health and increase fire threats so that we can act before damaging thresholds are crossed. Meaningful change within the sagebrush system over the long term may ultimately boil down to our ability to spatially identify and prevent these undesirable vegetation shifts. ${ }^{6}$ 


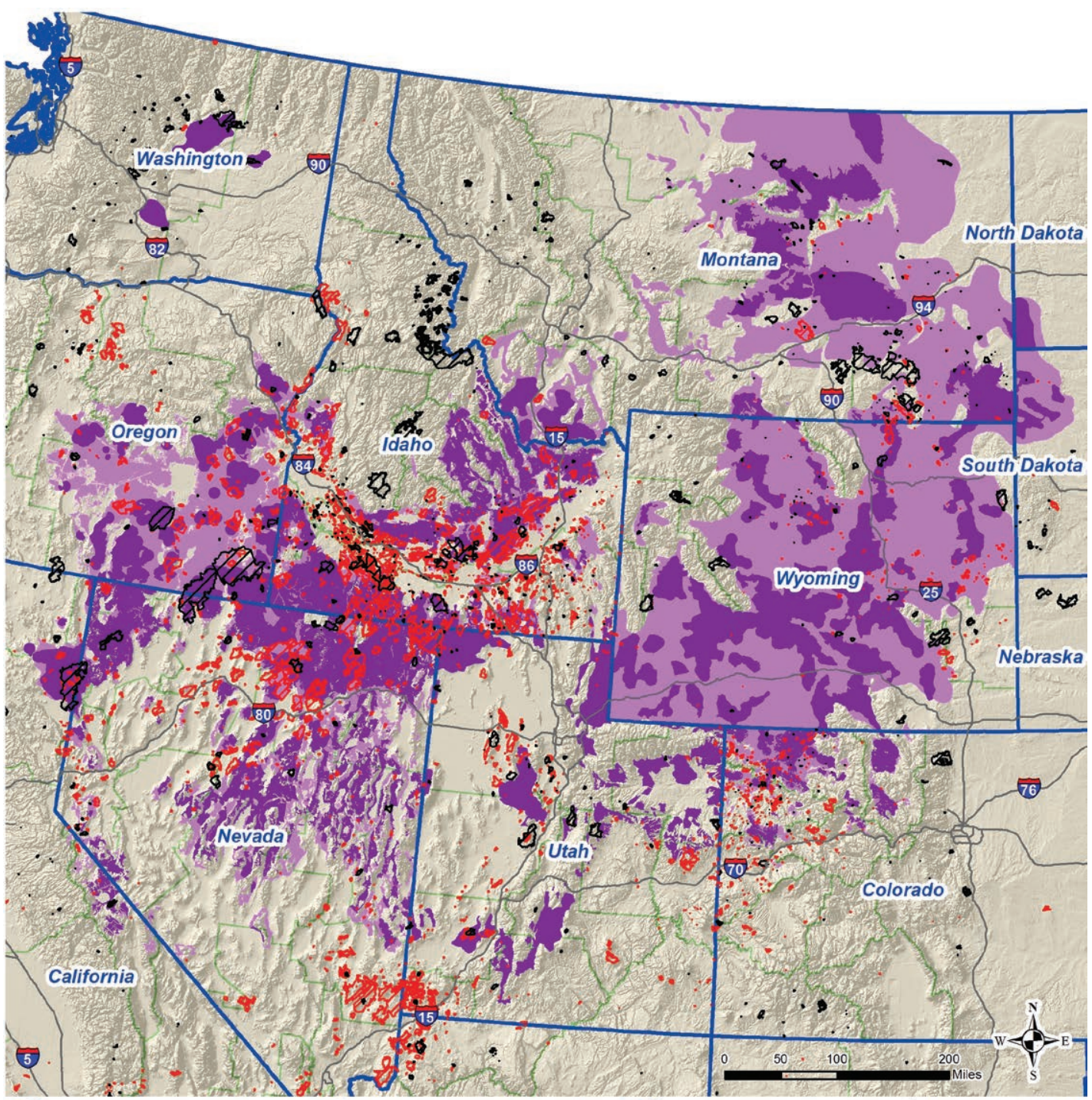

3 Preliminary Priority Habitat (PPH) $\backsim$ Preliminary General Habitat (PGH) CB Fire Perimeters 2000-2011 Z8 Fire Perimeters 2012

Figure 3. Locations of sage-grouse habitats and wildfire perimeters (2000-2012).

\section{Proactive Fuels Management Measures to Reduce Fire Size}

Fire managers stop most (up to 98\%) of starts in the initial attack stage from becoming larger wildfires, but the few that get away can wreak havoc (Table 1). Reducing the magnitude of those that get away requires continued partner engagement to find fully integrated and amenable solutions.

For example, while fire managers recommend a number of proactive, fuels-management techniques ${ }^{11,12}$ (Box 1), they recognize the need to work with biologists and other resource managers to craft locally supported and spatially explicit approaches to prioritize prevention efforts. In their sage-grouse conservation action plan presented recently to western governors, the Western Association of Fish and Wildlife Agencies embraced the concept of proactively establishing defensible fire lines in carefully selected locations to protect valuable sage-grouse habitat. ${ }^{13}$ Individual Great Basin states including Idaho, Nevada, Oregon, and Utah promote similar tactics in their state sage-grouse strategies. ${ }^{14-17}$ Still, additional engagement is necessary to hammer out local details including which practices to use, where to place them, and how to fund, implement, and maintain them. Only with local buy-in among stakeholders can we move forward with accelerated implementation at the scale necessary to reduce the threat of wildfire to sage-grouse.

\section{Fire Operations}

While the safety of firefighters and the public will always remain the top priority when responding to wildfire incidents, fire managers continually seek more effective tactics for protecting priority sagebrush 
Table 1. Extent of 2012 wildfires in sage-grouse habitat by state. A disproportionate amount of habitat loss due to fire occurred in the Great Basin.

\begin{tabular}{|c|c|c|c|c|}
\hline State & $\begin{array}{c}\text { Habitat } \\
\text { Type }\end{array}$ & $\begin{array}{l}\text { Total amount } \\
\quad \text { (acres) }\end{array}$ & $\begin{array}{l}\text { Amount burned in } \\
2012 \text { (acres) }\end{array}$ & $\begin{array}{l}\text { Percent burned } \\
\text { in } 2012\end{array}$ \\
\hline \multirow[t]{2}{*}{ CA } & $\mathrm{PGH}$ & 200,419 & 0 & $0.00 \%$ \\
\hline & $\mathrm{PPH}$ & $1,129,404$ & 258,653 & $22.90 \%$ \\
\hline \multirow[t]{2}{*}{$\mathrm{CO}$} & $\mathrm{PGH}$ & $1,486,068$ & 1,964 & $0.13 \%$ \\
\hline & $\mathrm{PPH}$ & $2,365,306$ & 2,543 & $0.11 \%$ \\
\hline \multirow[t]{2}{*}{ ID } & $\mathrm{PGH}$ & $4,520,426$ & 182,578 & $4.04 \%$ \\
\hline & $\mathrm{PPH}$ & $10,483,494$ & 341,834 & $3.26 \%$ \\
\hline \multirow[t]{2}{*}{ MT } & $\mathrm{PGH}$ & $24,963,378$ & 185,816 & $0.74 \%$ \\
\hline & $\mathrm{PPH}$ & $9,025,682$ & 23,159 & $0.26 \%$ \\
\hline \multirow[t]{2}{*}{ ND } & $\mathrm{PGH}$ & 243,471 & 0 & $0.00 \%$ \\
\hline & $\mathrm{PPH}$ & 460,167 & 0 & $0.00 \%$ \\
\hline \multirow[t]{2}{*}{ NV } & PGH & $5,853,824$ & 57,030 & $0.97 \%$ \\
\hline & $\mathrm{PPH}$ & $14,672,554$ & 381,364 & $2.60 \%$ \\
\hline \multirow[t]{2}{*}{ OR } & PGH & $8,253,397$ & 317,749 & $3.85 \%$ \\
\hline & $\mathrm{PPH}$ & $6,567,136$ & 688,075 & $10.48 \%$ \\
\hline \multirow[t]{2}{*}{ SD } & $\mathrm{PGH}$ & $1,534,564$ & 0 & $0.00 \%$ \\
\hline & $\mathrm{PPH}$ & 621,607 & 12 & $0.00 \%$ \\
\hline \multirow[t]{2}{*}{ UT } & $\mathrm{PGH}$ & 0 & 0 & $0.00 \%$ \\
\hline & $\mathrm{PPH}$ & $7,239,093$ & 37,990 & $0.52 \%$ \\
\hline \multirow[t]{2}{*}{ WA } & $\mathrm{PGH}$ & 0 & 0 & $0.00 \%$ \\
\hline & $\mathrm{PPH}$ & $1,277,919$ & 92,470 & $7.24 \%$ \\
\hline \multirow[t]{2}{*}{ WY } & PGH & $27,733,726$ & 100,095 & $0.36 \%$ \\
\hline & $\mathrm{PPH}$ & $15,792,109$ & 36,051 & $0.23 \%$ \\
\hline \multirow[t]{2}{*}{ Subtotal } & $\mathrm{PGH}$ & $74,789,273$ & 845,232 & $1.13 \%$ \\
\hline & $\mathrm{PPH}$ & $69,634,471$ & $1,862,151$ & $2.67 \%$ \\
\hline Total & & $144,423,744$ & $2,707,383$ & $1.87 \%$ \\
\hline
\end{tabular}


habitats during fires. Sage-grouse habitat is now an important factor considered in the type and number of initial response resources mobilized, but further advances in the predictive field will enable even better prepositioning of crews, equipment, and aircraft to places most needed. Opportunities also exist to expand safety and firefighting training for members of the ranching community to enhance their role in initial fire response, either directly or through an affiliation with their local rural fire department. Having the advantage of local knowledge, equipment, and proximity to fire starts, local landowners and rural communities can be important allies in slowing fire spread.

\section{Postfire Planning}

Postfire efforts are critical for determining the trajectory and pace of recovery and preventing irreversible resource damage, such as soil loss or conversion to annual grasslands. Guidance for planning postfire projects has been developed covering a number of elements, ranging from evaluating the risk and comparing the outcomes of implementing versus not implementing treatments, to considering the threat of repeat wildfires and designing revegetation plans with sustainability considerations. The guidance also suggests establishing Specific, Measurable, Attainable, Reasonable, and Time-based (SMART) objectives for treatment success with the realization that a return to desired vegetation conditions meeting land health standards may take longer than the three years allotted for Emergency Stabilization and Rehabilitation (ES\&R) program funding.

Emergency planning after large fires often strains capacity of personnel to develop the best plans possible given accelerated time requirements and short windows in which to expend rehabilitation funds. An evaluation of ES\&R procedures and policies could yield opportunities to improve flexibility for local staff to develop more targeted and effective rehabilitation plans. Outside of emergency planning, managers also need flexibility to respond to invasive species in the first few years following fire. Given the almost irreversible nature of annual grassland conversion with current technology, a discussion and consideration of all tools and management options is needed to effectively move forward with efforts to suppress annual grasses and encourage perennial plants in the postfire environment.

\section{Enhancing Rehabilitation}

Rehabilitating fire-affected lands through seeding or planting desired vegetation remains challenging, especially in Wyoming big sagebrush communities where windows for successful establishment of vegetation may be very limited. ${ }^{6}$ Vast resources can be expended to recover these important habitats but with low success rates. Quickly establishing perennial bunchgrasses on vulnerable lands is essential in

\section{Box 1. A Case for Proactive and Strategic Fuels Management}

Many people are surprised to learn that in any given fire season, more than $95 \%$ of all wildfire starts are contained in the initial attack stage, and some years that number may be as high as $98 \%$. That means nearly every wildfire is out by the day after it starts and before it can spread across the landscape.

That also means the small percentage of fires that escape initial attack often become large conflagrations that are resistant to control and cause severe damage to habitat and other resources. That $2-5 \%$ of all fires each year cause the largest expense, the most severe losses, and pose the greatest challenges for fire, land and resource managers. Frequently those few large fires result from conditions in the field, often on days when lightning causes multiple starts in highly flammable fuels accompanied by strong winds.

On those days, in those conditions, and typically in remote rangeland settings, there is no number of engines, aircraft, or equipment that can be effective in initial attack regardless how quick they respond. Given that set of conditions and the need to better conserve sage-grouse habitat, fire, fuels, and wildlife managers are contemplating the need for preventative practices to be implemented prefire to interrupt continuous fuels in priority habitats.

Establishing appropriately placed practices to reduce fuels prefire, such as fuel breaks, greenstripping, targeted grazing, or other locally agreed-upon techniques, can give firefighters a safe zone from which to compartmentalize fires and cut habitat losses. ${ }^{11,12,18}$ Local coordination with wildlife managers is essential to ensure these practices are carefully located, such as along existing roads or areas of existing annual grass invasion, to minimize habitat fragmentation in high-quality habitat. 
staving off competition from annual grasses, but re-establishing native species is still an unpredictable endeavor. Accelerating recovery of sagebrush on burned lands is particularly critical if landscapes are to support sagebrush-obligate species, but our ability to do so is in its infancy and additional partnerships need to be forged to succeed in this challenge.

Rehabilitation is a research frontier worthy of accelerated investment if we are to ever repair these communities. Fortunately, several promising efforts are underway including: testing of "Precision Restoration" techniques designed to improve seeding success, cutting-edge development of fungi and bacterium to inhibit annual grass production, the Joint Fire Science Program's SageSTEP project evaluating various methods to identify thresholds and improve rehabilitation, and the Great Basin Fire Science Delivery Project instituted to strengthen linkages between science and management.

A more integrated and consistent approach for funding rehabilitation efforts is also needed, as demonstrated in 2012, when necessary resources were woefully inadequate to protect the land and guard against invasive species. The urgency of the postfire situation was articulated by the Western Governors' Association in a 25 October 2012 letter to Congress requesting additional rehabilitation funding, "If the narrow fall planting window is missed, additional work to prevent the expansion of invasive weeds and the future threat of wildfires in sage-grouse habitat becomes an increasingly costly and reoccurring negative impact to the conservation of the species." Since we are likely to continue experiencing episodic years of large fires, a coalition of agencies and partners interested in sagebrush ecosystem conservation should explore opportunities to stabilize seed-buy programs and invest in storage facilities to ensure resources are available when needed.

\section{Monitoring}

As new prevention and rehabilitation techniques are being tried and tested, monitoring will become increasingly essential for measuring outcomes and informing adaptive management. Postfire projects in the Northern California District of BLM, for instance (Rush Fire ESR), are piloting the use of BLM's Assessment Inventory and Monitoring (AIM) framework, in which monitoring data is collected using a standard approach that will inform all resource programs, and be integrated into a landscape-level network so that information can be extrapolated beyond the project, to inform regional and national conditions and trends. Strong investment in monitoring is needed to ensure objectives are being met and to hone our ability to address wildfire and invasive species risks.

\section{Forging a Path Forward}

Large-scale wildfires in the Great Basin will continue to challenge land managers and sage-grouse conservationists well into the future. We fully acknowledge that fire prevention and suppression are not the ultimate solutions to fixing dysfunctional sagebrush ecosystems and these efforts must be coupled with long-term land management actions designed to improve ecosystem health and resiliency. However, fire and fuels management and rehabilitation have an important role to play in minimizing damage while other land managers work to resolve these longer-term challenges.

Slowing the pace and scale of habitat loss due to wildfire is not out of reach but will take an accelerated level of engagement between partners to fully create and implement a more effective path going forward. We suggest that the agencies of the Greater Sage-grouse Executive Oversight Committee and the Western Governors' Sage-Grouse Task Force empanel an interdisciplinary working group to develop strategic and tactical plans to address destructive wildfire. In order to improve our collective ability to address fire challenges, we felt it important to articulate steps already being taken by fire and fuels managers so that conversations and efforts may focus on addressing aspects that may be limiting our ability to achieve desired outcomes. We hope this paper heightens awareness of this issue and further accelerates a mutually agreed upon, spatially explicit path forward, so that all partners can quickly engage in its implementation.

\section{References}

1. [USFWS] United States Fish and Wildlife Service. 2010. 12-month finding for petitions to list the greater sage-grouse (Centrocercus urophasianus) as threatened or endangered; proposed rule. 75 Federal Register 13910. Available at: http://www.gpo.gov/fdsys/pkg/FR-2010-03-23/pdf/2010-5132.pdf. Accessed 26 April 2013.

2. Connelly, J. W., and C. E. Braun. 1997. Long-term changes in sage grouse Centrocercus urophasianus populations in western North America. Wildlife Biology 3:229-234.

3. Miller, R. F., And L. L. Eddleman. 2001. Spatial and temporal changes of sage-grouse habitat in the sagebrush biome. Corvallis, OR, USA: Oregon State University Agricultural Experiment Station. Technical Bulletin 151. 35 p. 
4. Miller, R. F., S. T. Knick, D. A. Pyke, C. W. Meinke, S. E. Hanser, M. J. Wisdom, and A. L. Hild. 2011. Characteristics of sagebrush habitats and limitations to long-term conservation. In: S. T. Knick and J. W. Connelly [EDS.]. Greater sage-grouse: ecology and conservation of a landscape species and its habitats. Berkeley, CA, USA: University of California Press. p. 145-184.

5. BAKer, W. L. 2011. Pre-Euro-American and recent fire in sagebrush ecosystems. In: S. T. Knick and J. W. Connelly [EDs.]. Greater sage-grouse: ecology and conservation of a landscape species and its habitats. Berkeley, CA, USA: University of California Press. p. 185-201.

6. Davies, K. W., C. S. Boyd, J. L. Beck, J. D. Bates, T.J. Svejcar, and M. A. Gregg. 2011. Saving the sagebrush sea: an ecosystem conservation plan for big sagebrush plant communities. Biological Conservation 144:2573-2584.

7. PYKe, D. A. 2011. Restoring and rehabilitating sagebrush habitats. In: S. T. Knick and J. W. Connelly [eds.]. Greater sage-grouse: ecology and conservation of a landscape species and its habitats. Studies in Avian Biology. Volume 38. Berkeley, CA, USA: University of California Press. p. 531-548.

8. Chambers, J. C., B. A. Roundy, R. R. Blank, S. E. Meyer, and A. Whittaker. 2007. What makes Great Basin sagebrush ecosystems invasible by Bromus tectorum? Ecological Monographs 77:117-145.

9. [BLM] Bureau of Land Management. 2011. Sage-grouse conservation related to wildland fire and fuels management. WO IM 2011-138. Available at: http://www.blm.gov/wo/st/en/prog/more/sagegrouse.html. Accessed 26 April 2013.

10. Westerling, A. L., T. J. Brown, A. Gershunov, D. R. Cayan, and M. D. Dettinger. 2003. Climate and wildfire in the western United States. Bulletin of the American Meteorological Society 84:595-604.

11. Diamond, J.M., C.A. Call, And N. Devoe. 2009. Effects of targeted cattle grazing on fire behavior of cheatgrass-dominated rangeland in the northern Great Basin, USA. International Journal of Wildland Fire 18:944-950.

12. Pellant, M. 1990. The cheatgrass-wildfire cycle—are there any solutions? In: E. D. McArthur, E. M. Romney, S. D. Smith, and P. T. Tueller [EDs.]. Proceedings—-symposium on cheatgrass invasion, shrub die-off, and other aspects of shrub biology and management; 5-7 April 1989; Las Vegas, NV, USA. Ogden, UT, USA: USDA Forest Service Intermountain Research Station. General Technical Report INT-276. p. 11-18.

13. Stiver, S. 2012. Near-term greater sage-grouse conservation action plan. Range-wide Interagency SageGrouse Conservation Team and Western Association of Fish and Wildlife Agencies. Unpublished Report presented to Greater Sage-Grouse Executive Oversight Committee and Sage-Grouse Task Force, Hilton Head, SC, USA. 27 p.

14. HaGen, C. A. 2011. Greater sage-grouse conservation assessment and strategy for Oregon: a plan to maintain and enhance populations and habitat. Salem, OR, USA: Oregon Department of Fish and Wildlife. 207 p.

15. State of Idaho. 2012. Federal alternative of Governor C. L. "Butch" Otter for greater sage-grouse management in Idaho. Available at: http://fishandgame.idaho.gov/public/wildlife/SGtaskForce/alternative.pdf. Accessed 26 April 2013.

16. State of Nevada. 2012. Strategic plan for conservation of greater sage-grouse in Nevada. Available at: http://sagebrusheco.nv.gov/uploadedFiles/sagebrusheconvgov/content/Archive/2012-07-31_FinalSagegrouseRecommendationsText.pdf. Accessed 26 April 2013.

17. [UDWR] Utah Division of Wildlife Resources. 2013. Conservation plan for greater sage-grouse in Utah. Salt Lake City, UT, USA: Utah Department of Natural Resources, Division of Wildlife Resources. Available at: http:// wildlife.utah.gov/uplandgame/sage-grouse/pdf/greater_sage_grouse_plan.pdf. Accessed 26 April 2013.

18. [BLM] Bureau of Land Management. 2010. Considerations for strategically reducing fuels and wildfires on public lands in the Great Basin with targeted grazing. Great Basin Restoration Initiative Workgroup. Boise, ID, USA: BLM Idaho State Office. 35 p.

Authors are Assistant Director, National Fire and Aviation, Bureau of Land Management, National Interagency Fire Center, Boise, ID 83705, USA (Murphy); National Science Advisor, Sage Grouse Initiative, and Professor, Wildlife Biology Program, University of Montana, Missoula, MT 59812, USA (Naugle); Deputy Chief, External Affairs, National Fire and Aviation, Bureau of Land Management, National Interagency Fire Center, Boise, ID 83705, USA, reardley@blm.gov (Eardley); National Technical Lead, Sage Grouse Initiative, USDA-NRCS, Redmond, OR 97756, USA (Maestas); National Coordinator, Sage Grouse Initiative, USDA-NRCS, Bozeman, MT 59715, USA (Griffiths); Coordinator, Great Basin Restoration Initiative, Bureau of Land Management, Boise, ID 83709, USA (Pellant); and Sage-Grouse Coordinator, Western Association of Fish and Wildlife Agencies, Prescott, AZ 86301, USA (Stiver). 